\title{
Evaluación de susceptibilidad in vitro de Staphylococcus spp
}

\author{
CHRYSTAL JULIET L. ${ }^{1}$ \\ EVALUATION OF Staphylococcus spp in vitro SUSCEPTIBILITY
}

Key words: In vitro susceptibility, Staphylococcus.

La resistencia a los $\beta$ lactámicos en el género Staphylococcus obedece a dos mecanismos:

- mediada por $\beta$ lactamasa. Afecta a los siguientes antimicrobianos: penicilina, ampicilina, amoxicilina, carbenicilina, azlocilina, mezlocilina, piperacilina y ticarcilina.

- mediada por PBP $2 a$ o intrínseca. Codificada por el gen mecA del cromosoma. Es el mecanismo que afecta a: meticilina, oxacilina, cloxacilina, flucloxacilina, nafcilina y todos los $\beta$ lactámicos, incluyendo cefalosporinas de todas las generaciones y combinaciones con inhibidores de $\beta$ lactamasas. Estas cepas son además resistentes a otros antimicrobianos. La expresión de esta resistencia puede ser heterogénea: todas las bacterias tienen el gen, pero sólo algunos lo expresan, u homogénea: todas las bacterias tienen el gen y lo expresan.

Existen cepas de Staphylococcus aureus con susceptibilidad in vitro peculiar:

- borderline: mediada por exceso de $\beta$ lactamasas, ¿otras PBPs ?. Se caracterizan por una CIM a oxacilina de $2 \mu \mathrm{g} / \mathrm{ml}$, resistencia que no es cruzada con otros $\beta$ lactámicos. Son susceptibles a inhibidores de $\beta$ lactamasas.

- tolerancia: se define por una relación entre CIM y CBM al menos igual a 1: 4 .

En las Tablas 1, 2 y 3 se detallan recomendaciones para la ejecución del estudio de susceptibilidad in vitro de Staphylococcus spp.

\section{Detección de la resistencia}

La expresión de la resistencia heterogénea o resistencia a cloxacilina -históricamente se utilizó meticilina para esta evalución in vitro acuñándose el término $S$. aureus "meticilina resistente" (SAMR) el que prevalece hasta hoy día aunque actualmente el test in vitro se efectúa con oxacilina por razones que se expresan en el texto- es afectada por los siguientes factores:

- osmolaridad: se expresa mejor en agar hiperosmolar $(\mathrm{NaCl} 4 \%)$.

- temperatura de incubación: se expresa mejor a $30^{\circ} \mathrm{C}$.

- medio de cultivo ( $\mathrm{pH}$ - cationes)

- tiempo de incubación: se requiere 24 a 48 hrs.

${ }^{1}$ Laboratorio de Microbiología, Hospital Del Salvador.

S 116 
Tabla 1. Requisitos para efectuar el test de susceptibilidad in vitro para Staphylococcus según técnica de difusión en agar (Kirby-Bauer)

(NCCLS - 2001)

\begin{tabular}{lll}
\hline Medio & $:$ & agar Mueller - Hinton \\
Inóculo & $:$ & suspensión bacteriana directa \\
Temperatura & $:$ & $35^{\circ} \mathrm{C}$ \\
Tiempo de incubación & $:$ & 24 hrs para oxacilina y vancomicina, \\
& $:$ & 16 a 18 hrs para otros \\
Lectura & luz trasmitida (por debajo de placa) \\
\hline
\end{tabular}

Tabla 2. Antimicrobianos a utilizar NCCLS - 2001

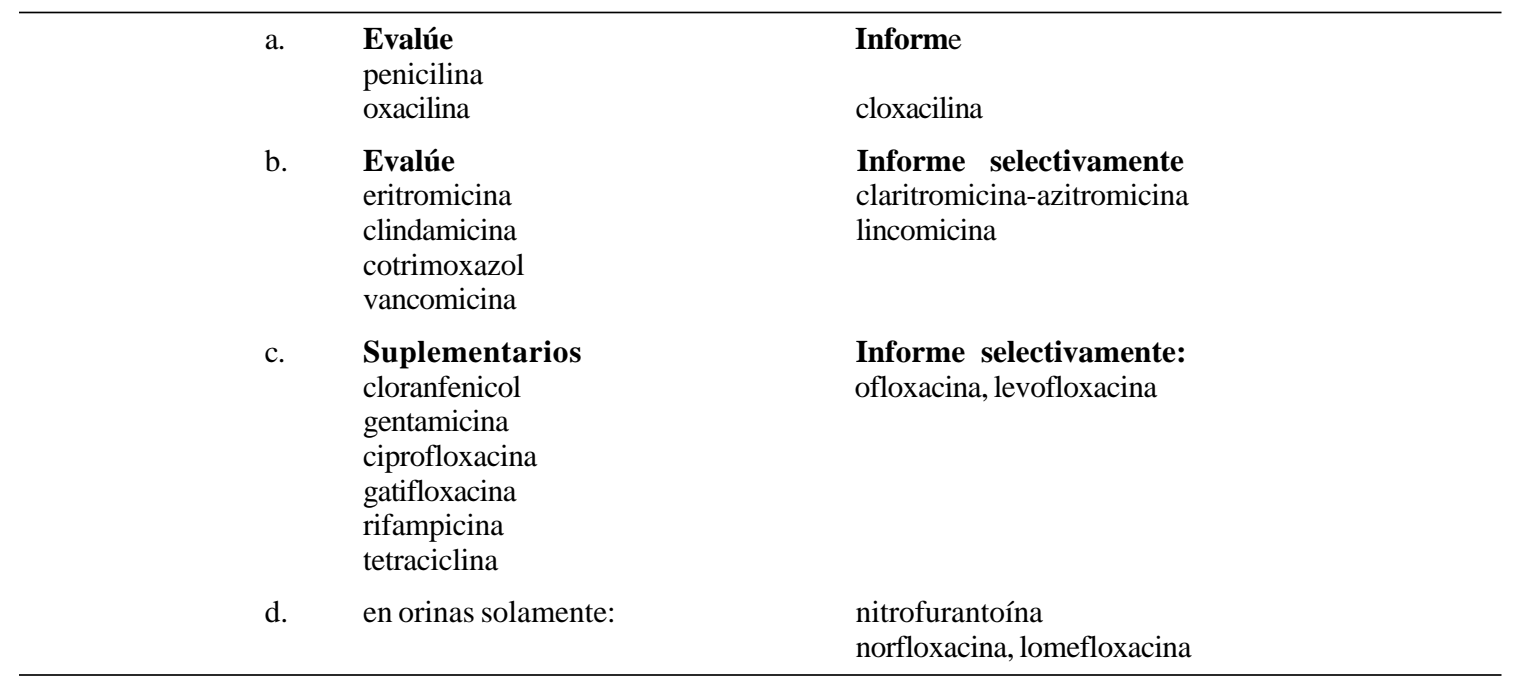

Tabla 3. Interpretación de halos de inhibición en test de difusión en agar (Kirby Bauer) para Staphylococcus

NCCLS - 2001

\begin{tabular}{|c|c|c|c|c|}
\hline Antimicrobiano & $\begin{array}{c}\text { Carga del } \\
\text { sensidisco }(\mu \mathrm{g})\end{array}$ & $\mathbf{R}^{*}$ & MS* & $\mathbf{S}^{*}$ \\
\hline Penicilina & $10 \mathrm{UI}$ & $<28$ & - & $>29$ \\
\hline Oxacilina & 1 & $<10$ & $11-12$ & $>13$ \\
\hline Oxacilina $S$. coagulasa neg. & 1 & $<17$ & - & $>18$ \\
\hline Vancomicina & 30 & - & - & $>15$ \\
\hline Eritromicina & 15 & $<13$ & $14-22$ & $>23$ \\
\hline Clindamicina & 2 & $<14$ & $15-20$ & $>21$ \\
\hline Cotrimoxazol (trimetoprim/sulfa) & $1 / 23$ & $<10$ & $11-15$ & $>16$ \\
\hline Tetraciclina & 30 & $<14$ & $15-18$ & $>19$ \\
\hline Ciprofloxacina & 5 & $<15$ & $16-20$ & $>21$ \\
\hline Gatifloxacina & 5 & $<14$ & $15-17$ & $>18$ \\
\hline Rifampicina & 5 & $<16$ & $17-19$ & $>20$ \\
\hline Gentamicina & 10 & $<12$ & $13-14$ & $>15$ \\
\hline Nitrofurano & 300 & $<14$ & $15-16$ & $>17$ \\
\hline
\end{tabular}


- tipo de $\beta$ lactámico: la cloxacilina no detecta la resistencia en un alto porcentaje de los casos. Se ha demostrado que oxacilina es la más adecuada para detectar la resistencia y es la más resistente y estable a la degradación del almacenamiento.

\section{COMENTARIOS}

- En Staphylococcus coagulasa negativa la resistencia a oxacilina se detecta mejor en agar hipersalado (test de screening).

- No se recomienda un estudio de susceptibilidad a Staphylococcus saprophyticus aislado de orina, puede observarse una falsa resistencia a oxacilina in vitro siendo la actividad clínica de los fármacos de elección -cotrimoxazol, nitrofurantoína, quinolonasmuy buena y predecible.
- Los Staphylococcus resistentes a oxacilina son generalmente multiresistentes, incluyendo aminoglucósidos, macrólidos, tetraciclinas y otros (es una clave para sospechar la resistencia a oxacilina).

- Los Staphylococcus spp pueden desarrollar resistencia a quinolonas durante un tratamiento con éstas, de manera que los aislamientos repetidos durante un curso de quinolonas deben ser sometidos a nuevos antibiogramas.

- A todos los Staphylococcus con halo de inhibición a vancomicina < a $14 \mathrm{~mm}$, se les debe determinar la CIM a vancomicina y enviar a un laboratorio de referencia.

- Si los resultados indican susceptibilidad intermedia para oxacilina, use el agar hipersalado con sensidisco de oxacilina como se describe en la Tabla 4.

Tabla 4. Test de screening para detectar resistencia in vitro a cloxacilina (NCCLS - 2001)

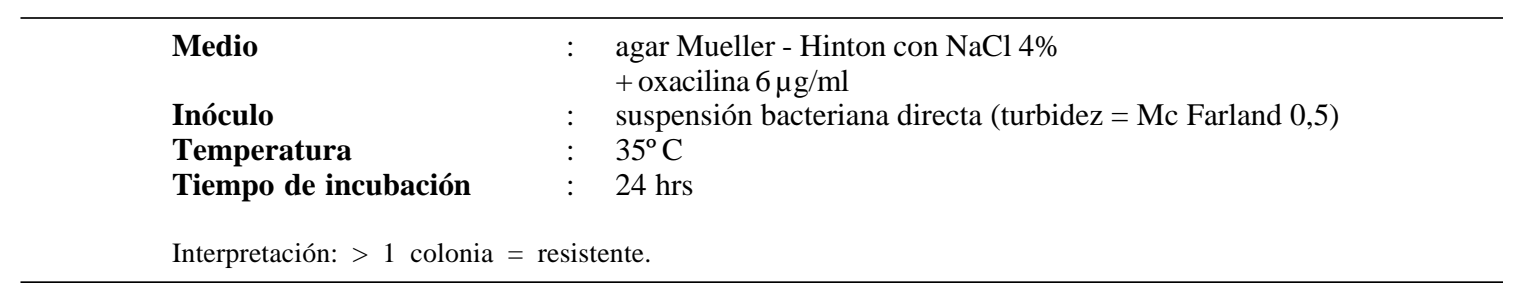

Correspondencia a:

Chrystal Juliet Larenas

E-mail: chjuliet@yahoo.com 